\title{
(一社)日本ゴム協会九州支部と
}

久留米工業高等専門学校との連携協定締結

一記念講演会とゴムの実践技術講座一

\section{Concluding Cooperation Agreement between The Society of Rubber Science and Technology, Japan, Local Chapter in The Kyushu Area and National Institute of Technology, Kurume College. \\ - The Commemorative Lecture Meeting and The Practical Training Courses for Rubber Processing -}

\author{
久留米工業高等専門学校生物応用化学科渡 邊 勝 宏 \\ 九州大学大学院工学研究院機械工学部門西村伸
}

(Received on November 24, 2017)

\section{1. はじめに}

（一社）日本ゴム協会九州支部（以下九州支部）と久留 米工業高等専門学校（以下久留米高専）は, 円滑かつ密接 な連携のもとに，地域ゴム産業の振興発展及び工業人材育 成の育成に寄与することを目的として平成 28 年 7 月に連 携・協力に関する協定を締結した，ここでは，協定締結及 び記念講演会に関する報告と連携協定の中心となるゴムの 人材育成事業に関する取り組みについて紹介する.

\section{2. 連 携協 定 締 結}

久留米高専は昭和 14 年に創立された旧制久留米工業高 等学校を淵源とし．昭和 17 年には工業化学科, 昭和 19 年 にはゴム工業科が開設された ${ }^{1)}$ ．以来様々な形で学校組織 が変遷しながらも，新制久留米高専として存続する現在に 至るまで，ゴムに関する研究は脈々と受け継がれており， 配合設計から混練，加硫，物性評価に至るまで一貫して展 開できる研究施設を有するまでに成長を遂げている，平成 30 年 6 月，九州支部は創立 70 周年を迎えるが，支部設立 から現在に至るまで，地域のゴム関連企業や大学・公設試 験機関とともに, 久留米高専も微力ながら支部の発展に貢 献してきた．特にゴム技術者の人材育成事業に関しては, 福岡県工業技術センターや(侏久留米リサーチ・パークと連 携し，企画・運営に携わってきた。平成 25 年より九州支 部主催で「ゴムの実践技術講座」が開催されるようにな り, 久留米高専も平成 26 年の第 2 回同講座より実施機関と して講座の企画・運営に協力している。

一方で, 久留米高専と九州支部との間でより強固な協力
関係を築き，地域連携・産学連携の観点で，地域ゴム産業 の振興発展及び工業人材育成に寄与していくべきとの気運 が高まり，平成 28 年 7 月 8 日，九州支部と久留米高専との 連携・協力に関する協定調印式が行われ，西村伸九州支部 長（当時）と三川譲二久留米高専校長により連携協定書が 執り交わされた（写真 $1 ， 2 ）$ 。この協定では, 主な連携事 項として(1)ゴム技術者の人材育成に関すること，(2)地域ゴ ム企業に対する技術支援に関すること，(3)産学連携交流促 進に関することを揭げている。調印式後, 九州支部のイベ ントの久留米高専での開催について協議を行い，毎年 8 月 に久留米高専にて開催している「ゴムの実践技術講座」に 加え, 平成 28 年度の第 4 回秋季ゴム・エラストマー技術講 座を連携協定締結記念講演会と称して久留米高専にて開催 することを決定した。

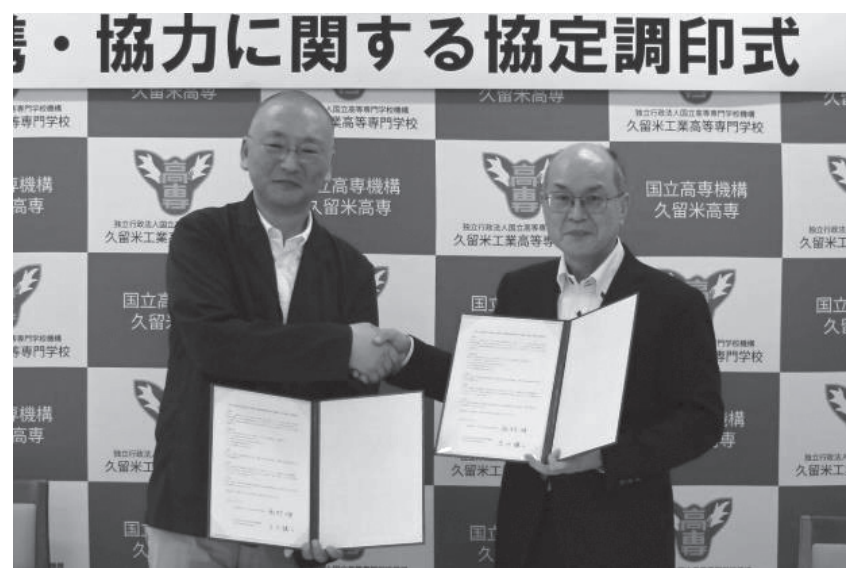

写真1 協定書を持ち握手を行う九州支部西村支部長（写真左）と久 留米高専三川校長 (写真右) 


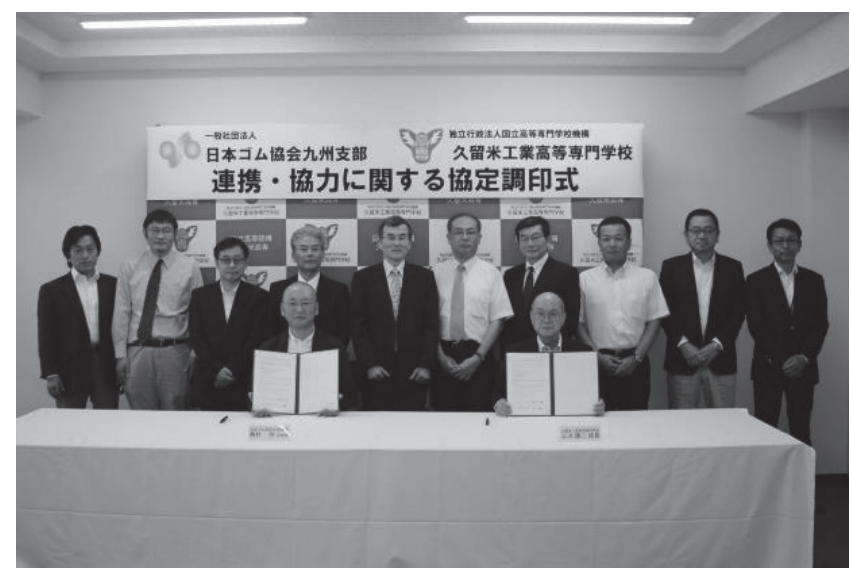

写真2 九州支部幹事と久留米高専関係者との記念撮影

\section{3. 連携協定締結記念講演会の開催}

九州支部では，毎年11月に秋季ゴム・エラストマー技 術講座を久留米市にて開催している。前述の通り平成 28 年 7 月に九州支部と久留米高専との間で連携・協力に関す る協定が締結されたのを記念し, 平成 28 年 11 月 25 日に 「第 4 回秋季ゴム・エラストマー技術講座」を久留米高専・ 九州支部連携協定締結記念講演会と称して久留米高専大講 義室にて開催した。本講座では，久留米高専三川譲二校長 (写真 3), 九州支部の西村伸支部長（当時）（写真4）の挨 拶の後,「ゴム材料の可視化技術」というテーマで以下の 講演を展開した。プログラム及び講演内容については以下 の通りである。

プログラム

$9: 30 \sim 9: 40$ 開会挨拶

久留米工業高等専門学校 校長 三川譲二

（一社）日本ゴム協会九州支部 支部長 西村伸

(座長) 実行委員 森哲夫（久留米工業高等専門学校名誉 教授)

9: 40〜 10：40「テラヘルツ分光法によるゴム可視化・評 価の可能性」久留米工業高等専門学校教授 平川靖之氏

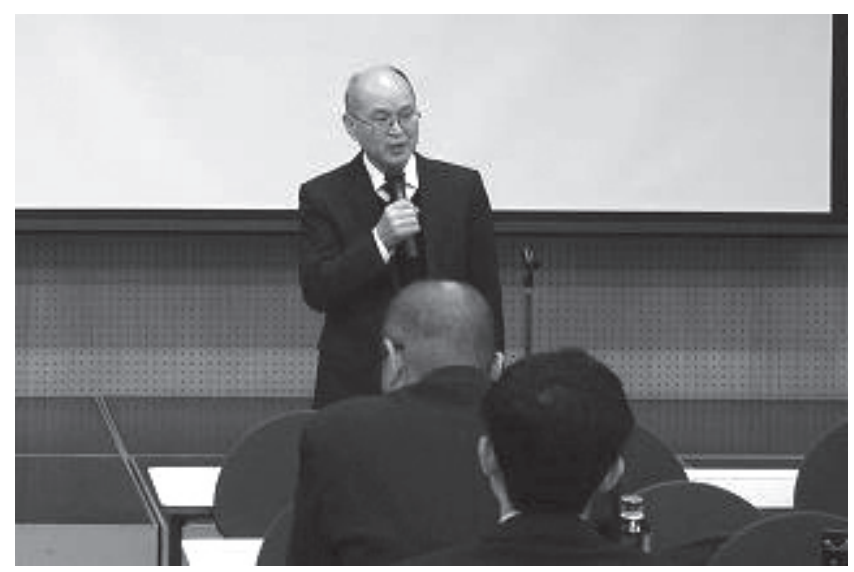

写真 3 開会挨拶する久留米高専三川校長

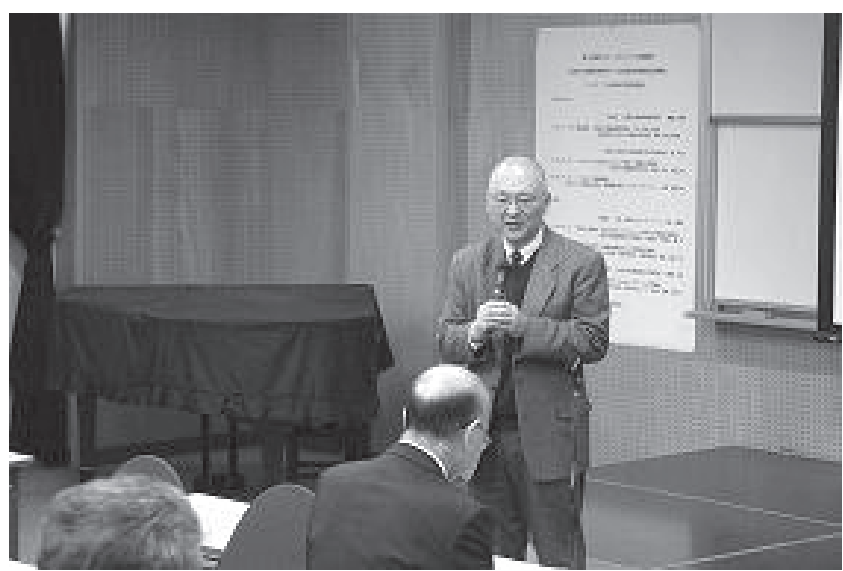

写真4 開会挨拶する九州支部西村支部長

テラヘルツ光や時間領域分光法の原理などの基本的な事項 に加えて, 実用化例と配合剂分散評価や加硫反応可視化な どのゴム製品評価への応用について講演がなされた。

$10: 40$ 〜 $12: 10$ 「ゴムのナノ構造解析」住友ゴム工業(株) 研究開発本部シニアリサーチャー 土肥英彦氏

ゴムの中の複雑な不均一構造を精密に可視化する技術で ある Nano Imaging Analysis と, ゴムの伸長挙動, ポリマ 一ノフィラー界面解析, 不均一架橋構造解析などに関する 講演がなされた。

(座長) 実行委員長 大㟝徹郎（侏久留米リサーチ・パー ク )

13:10〜 14:10「放射光X線散乱・回折法を利用したエ ラストマー材料の分子鎖凝集状態解析」九州大学先導物質 化学研究所准教授 小椎尾謙氏

高輝度 X線を用いた小角散乱／広角回折測定により，エ ラストマー材料に単純一軸伸長や周期的ひずみなどの力学 刺激下におけるミクロ相分離構造や結晶構造などの凝集構 造変化に関する講演がなされた。

$14: 10$ 〜 $15: 10$ 「放射光を利用した硫黄架橋配合ゴムの 架橋反応解析」(株)豊田中央研究所高分子成形 - 力学研究室 主席研究員 福森健三氏

放射光を利用した時分割 X線吸収微細構造測定 (XAFS) によるゴムの硫黄架橋反応解析法とXAFSスペクトルの 時間変化のその場観察に基づく架橋反応速度の評価に関す る講演がなされた。

(座長) 実行副委員長 小椎尾謙 (九州大学先導物質化学 研究所)

$15: 20$ 〜 $16: 20$ 「ナノ触診 AFM で解き明かすゴムのナ ノスケール力学物性」東京工業大学物質理工学研究院応用 化学系・応用化学コース教授 中嶋健氏

ナノ触診原子間力顕微鏡 (AFM) はナノスケールの空 間分解能で材料の力学物性を解析できるツールであり, こ れを用いてゴム・エラストマーの諸問題に適用した研究成 果について講演がなされた。 


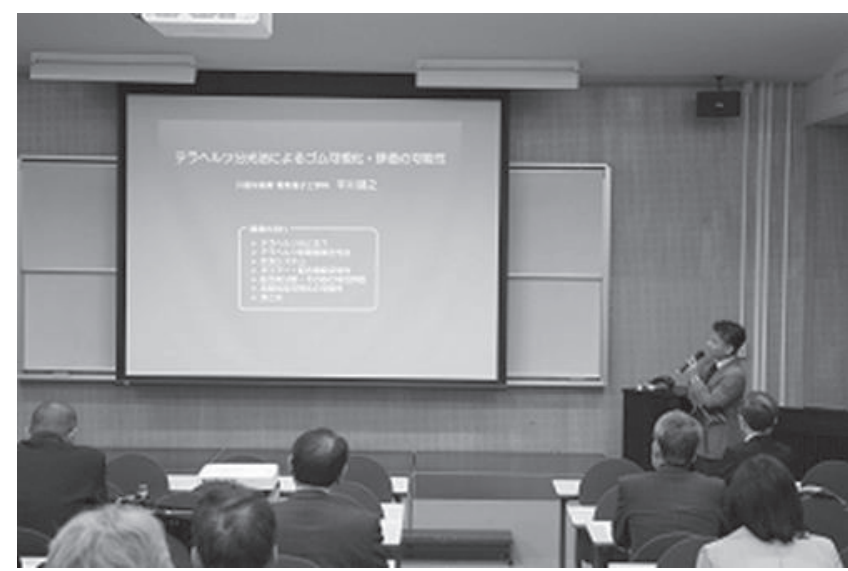

写真 5 講演会の様子

$16: 20 \sim 16: 30$ 閉会挨拶

実行委員長 大㠃徹郎（株久留米リサーチ・パーク）

第 4 回秋季ゴム・エラストマー技術講座実行委員会 実行委員長：大謧徹郎（株久留米リサーチ・パーク） 実行委員: 小椎尾謙 (九州大学先導物質科学研究所), 古 川睦久 (長崎大学名誉教授), 森哲夫 (久留米工業高等専 門学校名誉教授), 高橋良彰 (九州大学先導物質科学研究 所), 藤道治 (株久留米リサーチ・パーク), 藤原広匡 (九 州大学水素材料先端科学研究センター)

講演会は, 一般参加者に加え, 多くの久留米高専本科 $4 \cdot 5$ 年学生や専攻科学生が聴講した。普段の講義ではあ まり耳にしない最新の材料の可視化技術に触れ，自身が専 攻する専門分野の垣根を超えて新たな知見を得ることがで

き，有意義な講演会だったという感想を持った学生もい

て，盛会のうちに終えることができた（写真5).

また講演会終了後は会場をブリヂストンクラブに移し， 講師の方々並びに九州支部幹事, 久留米高専関係者が一同 に介しての懇親会が和気謁々とした雲囲気の中で催され， 有意義な宴席の時間を過ごすことができた。

\section{4. ゴムの人材育成事業に関する取り組みーゴムの実践技 術講座の実施}

久留米高専では, 近隣の公設試験機関である福岡工業技 術センターや(株)久留米リサーチ・パークと連携し, 平成 $18 \cdot 19$ 年度は経済産業省の委託事業として, 平成 $20 ２ 5$ 年度は同省の補助金を活用してゴム加工技術者人材育成講 座を開催してきた。

平成 $18 \cdot 19$ 年度 : 久留米地域若手リーダーゴム技術者 人材育成事業（高等専門学校等を活用した中小企業人材育 成事業), 平成 $20 \cdot 21$ 年度 : 福岡県自動車産業活性化人材 養成等事業 -人材養成等支援事業（地域企業立地促進等事 業費補助金), 平成 22 年度 : 福岡県・佐賀県・長崎県が広 域的に連携した北部九州自動車産業活性化人材養成等事
業 - 広域的人材養成等支援事業（地域企業立地促進等事業 費補助金), 平成 $23 \cdot 24 \cdot 25$ 年度 : 先端素材加工技術者養 成事業・ゴム, プラスチック, メッキの三分野の人材育成 事業（地域企業立地促進等事業費補助金）

これらの人材育成事業が実施された背景には, (1)久留米 地域は, 日本のゴム産業の草分け的地域で大手夕イヤメー カー, 履物メーカー, 中小ゴム企業が立地しゴム関連企業 の集積 (約 30 社) が進んでいること, (2)中国等からの安 価な海外製品との競合により夕イヤ関係を除いては低迷傾 向にあること, (3) 熟練技術者の引退に伴い, ゴム製品製造 に関する蓄積された経験・知識に基づいて現場の課題を解 決する「現場技術」の継承が危惧されていること, (4)九州 北部では自動車関連産業の拠点化が進んでおり, 自動車関 連産業の参入により久留米地域のゴム関連企業が活性化す る好機であるが, 高い技術力が求められることもあり, 参 入は十分進んでいないことが挙げられる。これらの課題を 解決すべく, ゴム製品の配合設計から加工, 検査, トラブ ル対策まで対応可能なゴム技術全般にわたる実践的知識と 最新の技術的知見を有し, 地域の研究資源を活用しつつ主 体的に製品開発など課題解決を図れる能力を身に着けた実 践的技術者の養成を目的として様々なゴム加工人材育成講 座が展開された ${ }^{2)}$.

平成 18 年度から平成 24 年度まで株久留米リサーチ・パ ーク ${ }^{2)}$, 平成 23 年度まで福岡県工業技術センター ${ }^{3)}$ 及び 久留米高専において, それぞれ各機関特有のテーマでゴム の実践的な実習が行われた。しかし，平成25年度からは， 九州支部主催の講座として事業化され，「ゴムの実践技術 講座」と称して開催されることとなった. 第 1 回は福岡県 工業技術センター単独での開催で「ゴムの組成分析とトラ ブル解析」のテーマで実習が開催された. 平成 26 年度の 第 2 回からは福岡県工業技術センターと久留米高専での開 催となり, 久留米高専では「練りと加硫における亜鉛華と ステアリン酸の挙動追跡」のテーマで実習が行われた。 こ の講座は, 実働 5 年程度のゴム技術者に対する実習内容に 特化し, 実習に加え, わかりやすく説明するためのプレゼ ン資料の作成までが実習内容に組み込まれており，実習終 了後は, 各受け入れ機関での報告に加え, 九州支部が 9 月 に開催する「ゴム技術・研究事例発表会」において実習報 告を行うようにルーチン化している. 平成 28 年には地元 自治体, 公設試験機関, 九州ゴム工業会, 九州支部, 久留 米高専による「ゴム技術者育成講座連携会議」が組織され 協議がなされた結果, 平成 29 年度より人材育成事業の見 直しがなされ, 上級・中堅技術者向けの実習を公設試験機 関が，初級技術者向けの実習を久留米高専が担当すること となった

平成 29 年 8 月 28 日から 31 日の日程で開催した第 5 回ゴ ムの実践技術講座では「ゴム技術のファーストステップ講 
座一基礎から実践まで ゴム材料の奥深さを知る」のテー マの下，実務経験 1 年未満の社会人ゴム技術者や大学・大 学院でゴムの研究に従事する学生を対象に, ラボスケール でゴム材料の製造プロセス全般に関する実技体験及び物性 評価を教授する内容に変更した，受講料も教育機関が協力 しての講座ということで, 会員 15,000円, 会員外20,000円, 学生無料と実習系講座としてはリーズナブルな価格設定に 変更した，具体的な実習内容については，加硫促進助剂の 亜鉛華とステアリン酸について, 練りでの添加方法や配合 量の違いが, 加硫反応に影響を及ぼすため, 久留米高専所 有の容量 1 リットルの密閉型二軸ゴム混練機（住友重機械 工業(株)製，以下ゴム混練機）を用い，加硫系を含まない混 練段階（A練り段階）における亜鉛華とステアリン酸の分 散性の評価を行うことを目的とした。ゴムコンパウンドの 調製過程におけるゴム混練機からの情報解析（消費電力, トルク, 内部温度等), 原子吸光分光光度計 (株)島津製作 所製，AA-670G）を用いたゴム中の亜鉛濃度の測定，加 硫特性・力学特性の評価に関する実習を行った。実習には 定員 5 名に対し，ゴムに関する実務経験が 1 年未満の若手 技術者 5 名に加え，ゴムの製造プロセスを体験したい大学 院学生 2 名を加えた 7 名が参加し, 以下のスケジュールで 実施した。

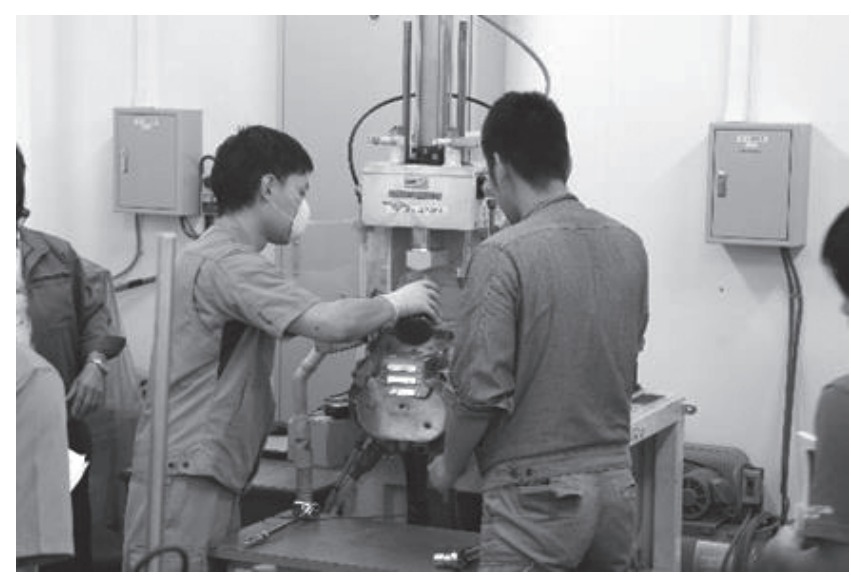

写真6 密閉型二軸ゴム混練機を用いたゴムコンパウンドの調製

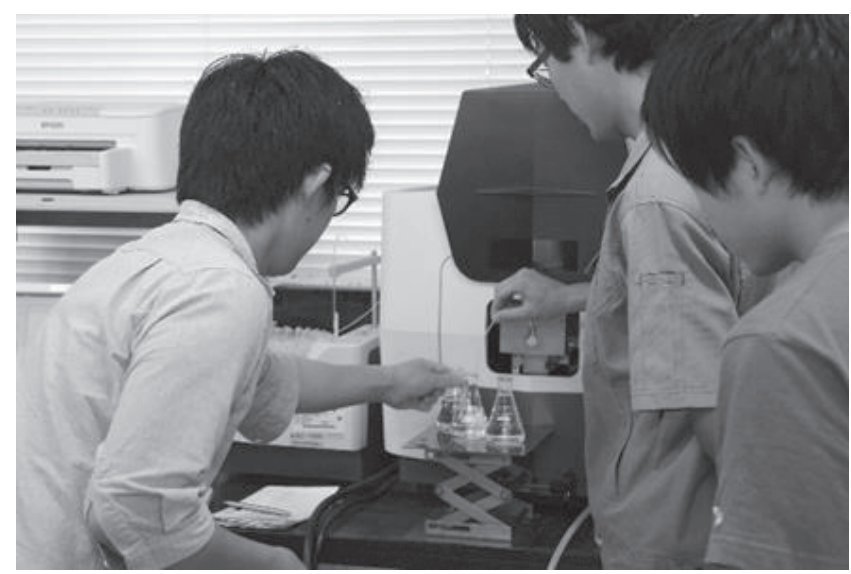

写真7 原子吸光分光光度計を用いたゴム中の亜鉛濃度の測定

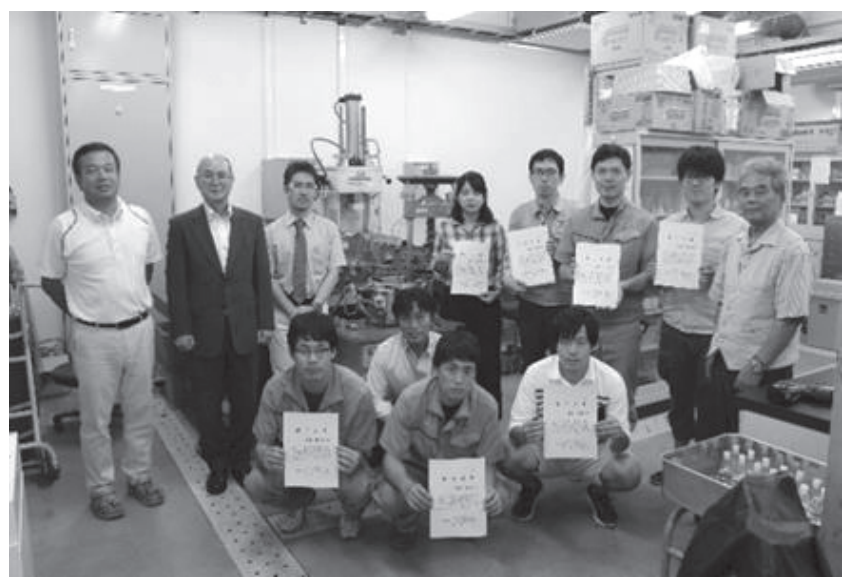

写真 8 閉講式後の記念撮影 (写真左から二人目が久留米高専三川校長)

1日目：午前：開講式, 実習概要説明

午後：配合設計，ゴム混練機を用いた混練（非カーボン配 合系, カーボン配合系の計 2 バッチ. B練り開始 10 分後, 及びダンプ時（開始40分後）でゴムを少量サンプリング した後，原子吸光測定用のサンプルの調製）（写真6）

2 日目・3日目：初日に調製したゴムサンプルについて加 硫特性（JSRトレーディング(株製，CURELASTOMETER W）力学特性（株エエーアンドデイ製, RTG-1310）の評価. 原子吸光分光光度計を用いたゴム中の亜鉛濃度の測定（ゴ ム中の亜鉛華の分散状況の評価）（写真7）

4 日目：データまとめ，プレゼン資料の作成，実習報告会 及び閉講式（写真 8)

講師：渡邊勝宏 (久留米高専生物応用化学科), 神野拓也, 権藤豊彦 (久留米高専教育研究支援室)

尚, 実習報告については, 平成 29 年 9 月 29 日に開催さ れた第29回ゴム技術・研究事例発表会において「ゴムの 実践技術講座報告 $(8 / 28 \sim 31$, 久留米高専 $) 」$ と題し, 受 講者5名で分担して成果発表を行った。

受講者は今まで触れたことがないゴム混練機によるコン パウンドの調製や各種分析機器類に直に触れての特性評価 を通じ，ラボスケールではあるがゴム製品の製造プロセス 全般について理解を深めていた。 また，実習中は講師に熱 心に質問するなどどん欲に技術を修得しようとする姿勢は 顕著であった。実習終了後のアンケートでは, 講座の内容 的には概ね満足の結果が得られていたが, 理論の説明をも う少し増やしてほしい, 実習データをまとめてプレゼン資 料等を作成する時間が少なかったのでもう少し時間を割い てほしいといった意見も見られ, 講座全体の内容の改善や 時間配分等改善し, 更に魅力ある講座にするべく努力して いきたい.

\section{5. お わ り に}

以上，九州支部と久留米高専との連携協定締結と記念講 演会開催報告とゴムの実践的技術講座について紹介した。 
学協会と高専との連携協定締結という事例は，全国的に見 ても極めて稀な事例であるが，開校以来一貫して受け継が れてきたゴムに関する研究設備を生かし，九州支部のます ますの発展に学校全体を挙げて協力していくと共に, 産学 連携 - 地域連携の観点から, 共同研究や人材育成事業等, 地域のゴム関連企業の発展に寄与すべく，魅力あるプログ ラムを企画立案・実施していきたいと考えている.

\section{参考文献}

1 ) 久留米工業高等専門学校 創基 75 周年 - 高専創立 50 周年記念誌 (2014)

2 ) 藤㠃崇芳, 姫野成以子, 黒木重則, 藤道治：日本ゴム協会誌, 86, 256 (2013)

3 ）井手誠二, 大㠃徹郎：日本ゴム協会誌，86，76（2013） 